\title{
ARTICULATING THE MARGINALIZED VOICES: SYMBOLISM IN AFRICAN AMERICAN, HISPANIC, AND ASIAN AMERICAN LITERATURE
}

\author{
Kristiawan Indriyanto \\ Universitas Gadjah Mada \\ kristiawanindriyanto@gmail.com
}

\begin{abstract}
The present study focuses on underlining the symbolism of selected minorities literature in the form of playscripts. Symbolism is employed by writers of ethnically minority in the United States as an avenue of their agency and criticism against the dominant white perspective. This study is a qualitative research which is conducted through the postnationalist American Studies framework in order to focus on the minorities' experience instead of the Anglo-Saxon outlook. Literature as a cultural production captures the experiences of the marginalized and the use of symbolism is intended to transform themes into the field of aesthetics. The object of the study is three playscripts written from authors from Mexican-American, African-American and Asian-American to emphasize how discrimination is faced by multi-ethnic. The study focuses on the symbolism employed by each writer and argues the reasoning behind the use of symbolism. The finding suggests how symbolism in these literary works intends to counter the stereotypical representation of Mexican-American, aligns with the passive resistance of the Civil Right Movement and subvert binary opposition of East and West which exoticizing the East.
\end{abstract}

Keywords: minority literature in the U.S, symbolism, post-national

\section{INTRODUCTION}

United States of America is a nation which historically is constructed from the assimilation and acculturation of many different cultures and ethnicities. The discovery of the continent of America in the $16^{\text {th }}$ century is a landmark of human mobility that results in the changing of demographics.(Jusdanis, 2001; Polk, 2006) The history of America is marked with racial inequality between the white settlers and the colored people. The indigenous Indians are marginalized by the arrival of the white settlers, followed by black slaves from the Africa due to the transatlantic slave trade for cheap labor in the plantations. Moreover, America acquisitions of the former territory of Mexico such as New Mexico, California and Nevada with the signing of the Treaty of Guadalupe Hidalgo in 1848 resulted in large numbers of formerly Mexican citizens to become American residents. (Boyer, 2012;

\section{British, Jurnal Bahasa dan Sastra Inggris}


Martinez, 1996) This event is followed by the discovery of gold in California, popularly known as the California Gold Rush which causes Asian immigration mainly Chinese - sails across the Pacific in dream for a better living. (Wilson, 1996) All of these cross-racial interaction results in the formation of America as a multi-ethnic and pluralistic society.

Although differentiated by historical, cultural, and societal background, a common experience of African-American, Chinese-American, and HispanicAmerican is segregation and marginalization due to their status as ethnic minorities. A brief explanation of the historical circumstances is important in underlining the oppression faced by the ethnic minority within the United States. The chronicle of black minorities in America is inseparable from their history as slaves, which persists until the aftermath of American Civil War.(Galtung, 1990; Paik \& Walberg, 2007; Smith, 2011) While after Civil War they are no longer treated as slaves or merely commodities for the whites, segregation in form of separate black schools and black public transportations still occur. The infamous Jim Crow law which officially enforce separate but equal is a defining moment for the marginalization of African American by the dominant whites.

Similarly, the ethnic minority which derived their origin from Mexico, the Mexican-American also experienced unjust treatment since the signing of Guadalupe Hidalgo Treaty. The signing of this treaty forcibly annexed a large geographical of area formerly owned by Mexico into the United States. The acquisition of the parts of modern day Arizona, California, New Mexico, Texas, Colorado, Nevada and Utah leads into a large numbers of Spanish speaking populace of the U.S. Viewed from the perspective of the white Americans, the Mexican-American are considered second-class citizens and are given stereotypical labelling as rapist, drug-dealers, illegal immigrant, and criminals. (Acuna, 1982; Hebebrand, 2004; Perez-Torres, 1995)

Differently from the historical circumstances of these aforementioned ethnicity, the descendants of Chinese immigrants in America was mainly motivated by the drive of seeking better life through the lure of economic richness. The propaganda of American Dreams fascinated the Chinese immigrants

\section{British, Jurnal Bahasa dan Sastra Inggris}


in the promise of having better life compared to the poverty in the war-torn China. The situation in America differed from what they expected, they were forced to work as common laborer in mines and plantations, all with harsh and putrid living condition. Moreover, they are subjected to false accusation of "yellow perils" due to their rapidly growing populace in the United States, their heathen pursuit of vice -gambling, idolatry, opium smoking- that terrified the Whites especially in San Francisco that the Chinese immigrant will soon take over their industry and economic sector.(Adams, 2008; Fitzsimmons et al., 2014; Hayashi, 2007) These irrational fears was later culminated in the forbidding of further Chinese immigrant through the Chinese Exclusion Act (1882-1942).

The Civil Rights Movements in the 1960's is considered the defining moment for the struggle of the minorities. The passage of certain laws such as Civil Rights Act of 1964 and the Voting Rights Act of 1965 which outlawed segregation in public accommodations, obstacles to the right to vote, and discrimination in employment is a landmark in the struggle of the minorities to achieve equal rights. (Boyer, 2012; Delgado \& Stefancic, 2013)Moreover, the draconic laws concerning immigration such as the Chinese Exclusion Acts is rappelled through the signing of the Immigrations Laws such as the Immigration and National Services Act of 1965 which enables easier entrance for immigrant to the United States. Yet although racism is now punishable by legal means, racial segregation remains an ongoing problem in U.S nowadays. In the hundred years since its formation, although America has moved into a more tolerant society, America remains unable to fully implement the concept of global citizen, "a single subject, within which all forms of difference are recognized and respected but conceptualized as internal to the substantive unity of all human beings."(Fine, 2007, p. 55)

The historical circumstances concerning the minorities' experience in the United States is reflected through the production of their literature. Literature, as a cultural product conveys the zeitgeist of its author, in this case particularly linked with a history of harassment and discrimination. The literature of minorities in the United States mainly concerns with the issues of racism, countering stereotypes, 
and avoiding assimilation into the wider White Anglo-Saxon Protestant (WASP) ethnic group. One study by Chandra (2020) contextualizes how novels written by Asian-American writers Amy Tan and Lisa See portrays the conflicts of identity by the female characters concerning the Chinese heritage and American influences. Furthermore, symbolism is a prominent aspect in Ethnic minority literature, in which the trope is employed figuratively to convey certain meaning distinct from its denotation. As noted by Baldick (1990, p. 231) symbol(ism) is an object or element incorporated into a narrative to represent another concept or concern, broadly, representing one thing with another. The usage of symbolism allows minority writers to convey certain aspects of their struggle against white domination through literary device.

To better contextualize the usage of symbolism in minority literature in the United States, this paper analyses several ethnically diverse literary works which employs symbolism. The paper explores one literary example each from the previously mentioned ethnic group, African American, Hispanic, and Asian American. Symbolism is important in literature because it stands for or suggests something else by reason of relationship, association, convention, or accidental resemblance. This paper explores how writers from those ethnicity employs symbolism in their literary work and its purpose in relation with minorities resistance toward the White oppression. There are three playscripts as the object of the study, Los Vendidos by a Mexican-American/Chicano writer, Florence, written by an African-American writer Alice Childress, and M. Butterfly as an example of Asian-American literature. This study asserts that these three playscripts contextualizes the usage of symbolism as an avenue of resisting racial discrimination.

Regarding the theoretical concept, this paper contextualizes how symbolism is employed by minority and diasporic writers to convey certain aspects particularly under the framework of American Studies. Symbolism in literature, as exemplified by Chadwick (1971, p. 50) is defined as "any mode of expression which, instead of referring to something directly refers to it indirectly through the medium of something else." The prior proponent of symbolism in American 
Studies exists under a school of thoughts, the myth and symbol popularized by Henry Nash Smith in Virgin Land (1950) and Charles Peirce (1955). The adherent of this theory asserts that myth and symbol are part of a same intellectual construction of a culture, the difference is that myth is a wider unit (such as the myth of American West as the Virgin Land) while symbol is the smaller parts which constitutes a myth (farmers, settlers, colonists, etc). Tate (1973, p. 16) considers the aforementioned myth and symbols as a necessity for a holistic understanding of American culture.

Scrutinizing myth and symbol schools of American Studies, the myth and symbols taken to represent American identity as a whole is only perceived from the white sides. For example, the conception that American West is a Virgin land fails to recognize that the West is actually not a wasteland but instead already being settled by indigenous Native American. Hence, by cultural appropriation of the wasteland, the White settler negates the existence of non-white ethnicity within the United States. This lack of concern results in the increasing need to incorporate myth and symbolism from other communities that constitutes United States. Symbolism of ethnically diverse minorities in the United States, as stated by Elizondo and Riggs is grounded "from the everyday reality they faced, the writer acts as the interpreter to the thoughts and feelings, many themes are radically transformed in order to bring them into the field of aesthetics." (Elizondo \& Riggs, 1977, p. 23) In other words, the prevalent use of symbolism in non-White writers is intertwined in the socio-cultural circumstances of their discrimination.

\section{RESEARCH METHOD}

This study is a qualitative research in which the primary data is three playscripts written by ethnic minorities in the United Stated. Qualitative research aims to explore and understanding individuals or groups ascribe to a social or human problem. The analysis is conducted under the framework of post-national American Studies. Post-nationalism in this contexts is perceived through the object of study as cultural production of minority groups within the United States.

\section{British, Jurnal Bahasa dan Sastra Inggris}


(Rowe, 2000, pp. 23-24). Rowe theorizes post-nationality in the conception of broadening American Studies perspective, in which the focus is not only on the white-centrist bias but problematizing other ethnicities that constitute the U.S. It can be stated that the paradigm of New American Studies criticizes the concept of nation, as a nation is not merely composed of singular ethnicity but also diverse racial background. Moreover, the shifting emphasis toward multiculturalism within American Studies enriches the discussion of American national identity to challenge the dominant Anglo-Saxon bias.(Carlos Rowe, 2012, p. 12; Curiel et al., 2000, p. 21)

\section{RESEARCH FINDING AND DISCUSSION}

This section exemplifies the use of symbolism in each literature, in which this literary device is employed by the author to convey their agency of resistance against the white domination. Each writer has their own distinct take on symbolism in response towards the different socio-cultural circumstances of their background. The symbolism in Hispanic literature, as seen in Los Vendidos satirizing the stereotypical depiction of people of Mexican descend of being drugdealers, criminal and violent thug. Differently, African-American literature, based on the reading of Florence captures the zeitgeist of the Civil Rights Movements by emphasizing passive resistance in line of the racial segregation. Lastly, the present study argues that symbolism in M.Butterfly subvert the binary opposition between the East and the West that designate the East as exotic, feminine and submissive by instead places the Asian character in the dominant gender role.

\section{Symbolism in Hispanic Literature: Los Vendidos}

Chicano literature is literature written by Mexican American in the United States. The word "Chicano" itself is Mexican Spanish abbreviation of Mexicanos that expressed pride in their ethnic heritage. (Sitkoff, 2000, p. 58) Chicano movement began to gain public consciousness in the 1960's, when Chicano's interest, as one ethnic minority in the United States aligns with other ethnicities such as the African-American, Asian-American or the Hawai'ian-American. In line with the awakening of racial pride of their distinct identity, the aim of

\section{British, Jurnal Bahasa dan Sastra Inggris}


Chicano literature is to establish an identity, to speak out and have that voice heard. (Agnew \& Roy, 2002, pp. 155-156; Basnett, 1993, p. 83) The emphasis of Chicano literature is on writing about identity, discrimination, culture, and history, with an emphasis on validating the Mexican American experience or Chicano culture in the United States. Another notable characteristic is their preference in writing bilingually, using both Spanish and English in their work.

Los Vendidos was written by Luis Valdez in 1967. As a playwright, Valdez is one of the pioneers of Chicano theatre in his creation of El Teatro Campesino. Los Vendidos is one of Valdez's earliest play as he later reaches prominence by his Zoot Suit (1978) which make him honored as the first Chicano writer to have a play published in Broadway in 1979. Los Vendidos is a notable example of Chicano literature with their own distinct characteristics such as using both English and Spanish. This subsequent section, taken from the script highlights the bilingualism of Los Vendidos through the monologue of Sancho.

SANCHO: Bueno, bueno, mis monos, vamos a ver a quién vendemos ahora, ¿no? (To audience.) iQuihubo! I'm Honest Sancho and this is my shop. Antes fui contratista, pero ahora logré tenermi negocito. All I need now is a customer. (A bell rings offstage.) Ay, a customer! (Valdez, 1971, p. 30)

As aforementioned, Los Vendidos is a satirical tale in which the characterization by the author intentionally conveys stereotypical depiction of Mexican-American community. Hence, this paper argues that the symbolism in Los Vendidos is how the characters are representing how the Chicanos are viewed from the dominant Whites perspective. Sancho is a seller of "model" or robot, in which he tries to persuade potential buyers, or in this play the secretary to buy his product. The notable aspects about the robots is that they represent stereotypical view of American people toward the Mexican-American. One robot, the "Farmer" is stereotypically resembling the poor Mexican people as their occupation is just plowing the land. Vardez illustrates how "farmer" is representing the Mexican immigrants near the border with Texas, they have no education and having to do 
menial labor work. Another model, "Johnny" is representing the urban immigrant, already "Americanized".

SANCHO: Ah, from the city! Step right back. Over here in this corner of the shop is exactly what you're looking for. Introducing our new 1969 JOHNNY PACHUCO model! This is our fast-back model. Streamlined. Built for speed, low-riding, city life. Take a look at some of these features. Mag shoes, dual exhausts, green chartruese paint-job, dark-tint windshield, a little poof on top. Let me just turn him on. (Snap. JOHNNY walks to stage center with a PACHUCO bounce.(Valdez, 1971, p. 34)

While the "farmer" embodied the poor immigrant near the border, "Johnny" is urban immigrant. We see from the name that Johnny Pachucho is the mixture of American name "Johnny" and Mexican name "Pachucho". This model is also showing the stereotypical view of the American as in this play Johnny is being called as "robber" and "marijuana user". In short Johnny's character symbolizes how the urban Mexican-American are merely considered as nuisance at best and criminal at worst.

Los Vendidos therefore explores the problematic identity of Chicano in the United States. Chicano are being treated similar to what Johnny is, potential troublemaker in the cities. Vardez explores the issue of identity not by exact mimesis, copying the life of the Chicano people to the stage but on a subtler way, by using characters as "robot" which embodied certain stereotypical aspect associated with the Chicano. Valdez wanted his audience to viewed how Chicano are being treated by the American, in the play it is the "secretary" which have such Anglo-American superiority in viewing Sancho's product as defect and useless. Based on the analysis, this paper asserts how Los Vendidos employs symbolism by robot as characters to depict the derogative view of the American people subtlety.

\section{Symbolism in African-American Literature: Alice Childress's}

\section{Florence}

Similar with Chicano movement, African-American ethnic movement employs theatrical performance to speak and voice their concern. Black Theatre movements flourished by several dramatists like Baraka with his Dutchman

\section{British, Jurnal Bahasa dan Sastra Inggris}


(1964) and Slaveship (1965). Differently with Valdez, Black Theatre movement focuses on the mimetic, realistically representing the oppression and marginalization they faced in their daily life into theatrical performance. Dutchman explores unapologetic denunciation of racism and its articulation of African American anger, in the subway confrontation between a seductive white woman, Lula, and her victim, a middle-class black man, Clay.(Bryer \& Hartig, 2010, p. 139) Written near the implementation of Civil Rights Act, Baraka's plays exemplify how black are still being racially abused while actually the law prohibit any form of harassment.

The racial segregation and demarcation between the whites and the blacks also becomes a pivotal theme in one play by Alice Childress, Florence. She is one of the pioneers of the Black Theatre Movement. Moreover, Childress holds the acclaim of being the first black female playwright to have a play professionally produced on the New York stage entitled Just a Little Simple (1950). She also holds the often-ignored distinction of being the only black woman whose plays have been produced professionally in America over four decades. Her writing is praised for its universality, uncompromising lack of sentimentality, powerful theatricality, realistic dialogue, and strong characters.(Bryer \& Hartig, 2010, p. 97)

Childress's first play, Florence (1949), is a one-act that depicts a conversation between a white woman and a black woman at a segregated bus station. Written during the ongoing racial demarcation between the whites and the whites, symbolism in Florence lies in the characters' action and how it reflects the zeitgeist of passive resistance by Martin Luther King Jr. King developed a philosophy of nonviolent civil disobedience based on the teachings of Indian pacifist Mohandas Gandhi and the American transcendentalist writer Henry David, in his view, "If we are arrested every day don't ever let anyone pull you so low as to hate them. We must use the weapon of love."(Sitkoff, 2000, p. 63) The act of nonviolence is rejected by the "black power" the slogan of militant blacks who rejected the nonviolence of Martin Luther King, Jr., and the moderate goals 
of the early civil rights movement. Florence, written by Childress aligns more with the passive resistance of King instead of the more radical black movements.

Florence represents the situation faced by the ethnic minority in the U.S during the era of segregation. The separate but equal law firmly forbid any form of social mixing among races in which there exist a separate public facilities, educational system, and religious building for the whites and the blacks. The dialogues between Marge and Mama establish Florence's characteristics as a strong willed girl, willing to enroll in any job even though at that time, salesgirl for example is not open for "colored" folks.

MARGE. I don't mean that. I'm talkin' about her attitude. Didn't she go to Strumley down there and ask to be a salesgirl? (rises) Now ain't that somethin'? They don't hire no Colored folks

MAMA. Other beside Florence been talkin' about their rights.

MARGE. I know it...but there's something we can't do cause they ain't gonna let us. (She wanders over to the "White" side of the stage.) Don't feel a damn bit different over here than it does on our side. (silence) (Childress, 2000, p. 6)

The dialogues illustrate the growing awareness of the inequality, and the ongoing Civil Rights Movement to reach quality. In the play, Marge acknowledges that the white side of the stage is not different to the black side, but the law prohibits them to be seated to the white side. Hence, the characters in Florence symbolizes the Civil Right movement in how they start to question the repression and taking steps to gaining more privilege. Moreover, the language in the play also represent their pride in using their daily speech and grammatical pattern in a theatrical performance to better convey the mimetic aspect. The use of Black English Vernacular (BEV) is considered to be an integral part of their identity and selfconcept.

Another symbolism regarding the Civil Rights movement is how the message in Florence is more attuned to the spirit of the passive resistance of King compared to the black power movement. In the climax of Florence a white woman (Mrs Carter) wanted to hire Florence, but as a maid instead of as an

\section{British, Jurnal Bahasa dan Sastra Inggris}


actress. While Mama is outraged, she managed to control her emotion and does not result in hitting Mrs. Carter physically.

MRS.CARTER. Of course she must be steady. I couldn't ask Melba to take a fly-by night. (Touches MAMA) But she'll have her own room and bath, and above all...security.

MAMA. (reaches out, clutches MRS. CARTER's wrist almost putting her off balance). Child!

MRS.CARTER (frightened) You're hurting my wrist.

MAMA. (looks down, realizes how tight she's clutching her, and releases her wrist.) I mustn't hurt you, must I.(Childress, 2000, p. 20)

Mama's action, in how she does not want to hurt Mrs. Carter even though she is deliberately provoking her emotion by asking her to allow Florence as Mrs. Carter's servant symbolizes the passive resistance. The principle of King is no matter what the white do to you endure it. Hence, Mama managed to control her emotion in connection with King's principle. In the end of the play, Mama writes a letter to Florence implore her to, "keep trying." Florence is trying to gain her place in a world still dominated with white centered domination. To conclude the analysis in this section, it can be said that Florence captures the zeitgeist of the era through its critique toward forced separation and the necessity of passive resistance to challenge white supremacy.

\section{Symbolism in Asian American Literature: David Henry Hwang's} M.Butterfly

Lastly, this paper highlights the usage of symbolism in Hwang's M.Butterfly. Hwang's full name illustrates the duality of his identity, as "David Henry" is American name while Hwang is Chinese surname. His interest is writing play about how people of different cultures and genders perceive and react to each other; therefore, the fluidity of identity is a theme common to most of his work. Hwang became the first Chinese-American dramatist to win a Tony Award with M. Butterfly (1988). In M.Butterfly Hwang makes allusion to previous play written in 1904, Puccini's Madama Butterfly, as seen in how the title resembles prior literary production. Yet Hwang deliberately just used " $M$ " instead of 
"Madama or Madame" to let his audience have their own interpretation. The play M. Butterfly, as exemplifies by Bryan and Hartig is

a play about love affair between a French diplomat and a Chinese opera actor and spy, explores issues of gender expectation, imperialism, identity, and relationships. M.Butterfly operates within a similarly dichotomous vision of East versus West. Set in late 1960s Beijing and Paris, the play examines fundamental cultural binaries: Eastern versus Western courtship rituals; Communist China's political and social oppressiveness versus the democratic West's freedoms; gender expectations of the virile Western male seducer versus the submissive Eastern female; Chinese opera versus Western opera.(2010, p. 258)

Another notable aspect in M.Butterfly is Hwang's intention to subvert the notion of binary opposition in which his script intends to scrutizine the East-West relationship. Hwang uses the symbolism of "butterfly" to deconstruct the stereotypical relationship Western man and Oriental women. The relationship between East and West, which is articulated by Edward Said's Orientalism (1977) is based on stereotypical depiction of the East. In Said's words, the Orient is the Western invention and had been a place of romance and exotic beings. (1977, p. 18). This notion of exoticizing the East is employed to legitimize the hierarchical status between the Occident and the Orient. As Indriyanto argues in his prior study, colonial discourse that regulate the relationship between colonizers and colonized functions through binary opposition of superiority and inferiority. (Indriyanto, 2020, p. 64)

M. Butterfly is based on a real story about the relationship between a French diplomat and Chinese "actress", it is only later in their relationship that the actress turn out not just to be a spy but also a man. In M.Butterfly, the character Gallimard is the French diplomat and Song is the actress. Gallimard is portrayed as a modern Western man, and he viewed himself as superior and hence having dominating perspective toward Oriental character like Song. He is obsessed with the notion of "butterfly" as exotic and submissive Oriental women, and when he sees Song's performance he was entranced by "her" performance.

GALLIMARD. Here... here was a Butterfly with little or no voice-but she had the grace,,,the delicacy...I believed this girl. I believed her

\section{British, Jurnal Bahasa dan Sastra Inggris}


suffering. I wanted to take her in my arms-so delicate, even I could protect her, take her home, pamper her until she smiled. (Hwang, 1988, p. 17)

From the quotation, it can be stated how the character of Gallimard affirms with the Western conception of the East as exotic and submissive. To prove his masculinity, Gallimard seeks relationship with Oriental woman which he believed to be tender and easily exploited. Hence, Gallimard's conception of the East is based on a false image that designate the East as the feminine one. While Gallimard had married, his marriage is merely to advance his career as a diplomat and he keep searching for "fantasy woman." He believed that the easily dominated but exotic Oriental woman is his perfect view of what "fantasy woman" should be.

Through his play script, Hwang subverts the binary opposition between East and West by placing his Asian character as the dominant one in the relationship. The notion of dominant western man and submissive oriental woman is subverted by how the "Butterfly" is later revealed to be a man seeking relationship with Gallimard in order to blackmailing him to give secret military secret for the Chinese's benefits. During the trial of Gallimard, where he is accused of giving secret information Song delivers this line that to convey the deconstruction of East and West relationship.

SONG. You expects Oriental countries to submit to your guns, and you expect Oriental women to be submissive to your men. That's why you say they make the best wives. (Hwang, 1988, p. 62)

By revealing that "Butterfly" is actually an Oriental man, Hwang subverts the notion that the West always dominating, always viewed the Orient as submissive and able to be exploited. In their relationship, while Gallimard viewed that himself is the dominant partner, actually it is Song who is manipulating him by posing himself as a "fantasy woman and using his status to persuade Gallimard in transferring secret information for the benefits of the Chinese government." Hence, we see how East-West relationship is being reconsidered by posing the East as dominant compared to the West. "Butterfly" is in itself a symbol, butterfly 
who is considered as a fragile but beautiful object in Hwang's play become more like a "dragon" in who the considered weaker partner is actually the one pulling the strings in the relationship.

\section{CONCLUSION AND SUGGESTION}

Based on the analysis of three playscripts written by ethnic minorities in the United States, this paper argues how symbolism in each text is employed as an avenue of resistance. The hidden meanings of symbolism allow the writers to articulate their intention whether to confirm of subvert common tropes in literature. Los Vendidos, through the satirical depiction of its characters criticizes the stereotypical depiction of Mexican-American merely as troublemakers, drug dealers and criminals. Differently, Florence which was written during the segregation period employs symbolism through the action of the characters to confirm with the passive resistance addressed by King Jr. Lastly, Butterfly by Hwang subverts the binary opposition of the East-West relationship that exoticizing Asian females. By revealing that the Asian woman is actually a man that control the Western character, Hwang reconceptualizes the relationship between the East and the West.

Several brief commentaries are addressed for future researches concerning the issues of ethnical minority in the United States. As articulated by the analysis of symbolism, although the writers come from diverse background, there exist a recurring literary device in the form of symbolism. Hence, any future researches can problematize other similarity in the form of characters, themes, plots, or the settings. Secondly, an interesting avenue to explore on the issue of minorities literature is the literary works from other ethnicities such as the Native Americans or Hawai'ian Americans. Their historical contexts of forced displacement from their homeland is a notable topic to ponder.

\section{REFERENCES}

Acuna, R. F. (1982). Occupied America : A History of Chicanos. Canfield PRess.

Adams, B. (2008). Asian American Literature. Edinburgh University Press. 
Agnew, J.-C., \& Roy, R. (2002). A Companion to post-1945 America. Blackwell Publishing.

Baldick, C. (1990). the Oxford Dictionary of Literary Terms. Oxford University Press.

Basnett, S. (1993). Comparative Literature. Blackwell Publishing.

Boyer, P. S. (2012). American History: A Very Short Introduction. Oxford University Press. https://doi.org/10.1017/CBO9781107415324.004

Bryer, J. R., \& Hartig, M. C. (2010). the Facts on File Companion to American Drama. Facts on File.

Carlos Rowe, J. (2012). The Cultural Politics of the New American Studies. University of Michigan Library.

Chadwick, C. (1971). Symbolism (Methuen \&).

Chandra, T. M. (2020). the Dynamic of Chinese Women in America: The Departure, Double Oppressions and Conflict of Identities in Amy Tan's and Lisa See's Selected Novel [Sanata Dharma University]. https://doi.org/10.11693/hyhz20181000233

Childress, Al. (2000). Florence. In K. A. Perkins (Ed.), Selected Plays : Alice Childress (pp. 3-22). Northwestern University Press.

Curiel, B. B., Kazanjian, D., Kinney, K., Mailloux, S., Mechling, J., Rowe, J. C., Sánchez, G., Streeby, S., \& Yu, H. (2000). Introduction. In J. C. Rowe (Ed.), Post-Nationalist American Studies (pp. 1-22). University of California Press.

Delgado, R., \& Stefancic, J. (2013). Critical Race Theory. In Racialisation in Early Years Education (2nd ed.). Temple University Press. https://doi.org/10.4324/9781315101071-2

Elizondo, S. D., \& Riggs, D. W. (1977). Myth and Reality in Chicano Literature. Latin American Literary Review, 5(10), 23-31.

Fine, R. (2007). Cosmopolitanism : Key Ideas. Routledge.

Fitzsimmons, L., Chae, Y., \& Adams, B. (2014). Asian American Literature and the Environment. Routledge.

Galtung, J. (1990). Cultural Violence. Journal of Peace Research, 27(3), 291305. 
Hayashi, R. T. (2007). Beyond Walden Pond: Asian American Literature and the Limits of Ecocriticism. In A. Merrill Ingram, I. Marshall, D. J. Phillipon, \& A. W. Sweeting (Eds.), Coming into Contacts: Explorations in Ecocritical Theory and Practice (pp. 58-74). University of Georgia Press.

Hebebrand, C. M. (2004). Native American and chicano/a literature of the American southwest: Intersections of indigenous literatures. Routledge. https://doi.org/10.4324/9780203330265

Hwang, D. H. (1988). M. Butterfly. Dramatists Play Service, Inc.

Indriyanto, K. (2020). MANIFESTATION OF COLONIAL DISCOURSE AND ANTHROPOCENTRIC OUTLOOK IN JAMES MICHENER ' S HAWAI ' I. Okara: Jurnal Bahasa Dan Sastra, 14(1), 51-66. https://doi.org/10.19105/ojbs.v14i1.3185

Jusdanis, G. (2001). The Necessary Nation. Princeton University Press.

Martinez, O. J. (1996). U.S - Mexico Borderlands : Historical and Contemporary Perspectives. Rowman \& Littlefield Publishers, Inc.

Paik, S., \& Walberg, H. J. (2007). Narrowing the Achievement Gap : Strategies for Educating Latino, Black, and Asian Students. Springer Science Business Media, LLC. https://doi.org/10.1007/0-387-44611-7

Perez-Torres, R. (1995). Movements in Chicano Poetry: Against Myths, Against Margin. Cambridge University Press.

Polk, W. R. (2006). The Birth of America: From Before Columbus to the Revolution. Harper Collins. https://doi.org/10.5949/liverpool/9780859896153.003.0003

Rowe, J. C. (2000). Post-Nationalism, Globalism, and the New American Studies. In J. C. Rowe (Ed.), Post-Nationalist American Studies (pp. 23-39). University of California Press.

Sitkoff, H. (2000). Postwar America : A Student Companion. Oxford University Press.

Smith, T. W. (2011). Changing Racial Labels from Colored to Negro to African American. Oxford University Press.

Tate, C. F. (1973). The Search for a Method in American Studies. University of Minnesota Press.

\section{British, Jurnal Bahasa dan Sastra Inggris}


Valdez, L. (1971). Luis Valdez - Early Works : Actos, Bernabe and Pensamiento Serpentino. Arte Publico Press.

Wilson, S. (1996). The California Gold Rush: Chinese Laborers in America: 1848-1882. the Rosen Publishing Group, Inc. 